\title{
ERRATUM
}

\section{Activation of the JAK/STAT pathway in Behcet's disease}

A Tulunay ${ }^{1}$, MG Dozmorov ${ }^{2,3}$, F Ture-Ozdemir ${ }^{1}$, V Yilmaz ${ }^{4}$, E Eksioglu-Demiralp ${ }^{1}$, F Alibaz-Oner ${ }^{5}$, G Ozen $^{5}$, JD Wren $^{2}$, G Saruhan-Direskeneli ${ }^{4}, \mathrm{AH}$ Sawalha ${ }^{6}$ and $\mathrm{H}_{\text {Direskeneli }}{ }^{5}$

Genes and Immunity (2015) 16, 176; doi:10.1038/gene.2014.80

Correction to: Genes and Immunity (2015) 16, 170-175; doi:10.1038/ gene.2014.64; published online 20 November 2014

Since the online publication of this paper, the authors have noted the following errors.

The author JD Wren was incorrectly linked to affiliation 1 instead of affiliation 2. The correct details are shown above.

In Figure 1 legend, the incorrect acronym INF was used for interferon. The correct figure legend is Canonical pathways activated in CD14+ monocytes in BD. (a) JAK/STAT signaling pathway. (b) IFN signaling pathway. (c) IL-6 signaling pathway. Red color indicates genes that are upregulated in patients compared to controls.

The typesetters would like to apologize for any inconvenience caused.

This error has now been rectified, and the corrected article appears in this issue. The html and online pdf versions have also been rectified, and now carry the corrected paper. 